\title{
Occurrence of Banned and Currently Used Herbicides, in Groundwater of Northern Greece; A Human Health Risk Assessment Approach
}

\section{Paraskevas Parlakidis}

Democritus University of Thrace: Demokriteio Panepistemio Thrakes

\section{Soledad Maria Rodriguez}

Universidad de Buenos Aires

\section{Christos Alexoudis}

Democritus University of Thrace: Demokriteio Panepistemio Thrakes

\section{Greivin Perez-Rojas}

Costa Rica University: Universidad de Costa Rica

\section{Marta Perez-Villanueva}

Costa Rica University: Universidad de Costa Rica

\section{Alejandro Perez Carrera}

Universidad de Buenos Aires

\section{Alicia Fernández-Cirelli \\ Universidad de Buenos Aires}

Zisis Vryzas ( $\nabla$ zvryzas@agro.duth.gr)

Democritus University of Thrace: Demokriteio Panepistemio Thrakes https://orcid.org/0000-00034396-4398

\section{Research Article}

Keywords: herbicides, metabolites, banned pesticides, groundwater, preferential flow, leaching.

Posted Date: March 11th, 2021

DOI: https://doi.org/10.21203/rs.3.rs-272200/v1

License: (c) (i) This work is licensed under a Creative Commons Attribution 4.0 International License. Read Full License 
1 Occurrence of banned and currently used herbicides, in groundwater of Northern

2 Greece; A human health risk assessment approach

3

4 Paraskevas Parlakidis ${ }^{\mathrm{a}}$, Soledad Maria Rodriguez ${ }^{\mathrm{a}, \mathrm{b}}$, Christos Alexoudis ${ }^{\mathrm{a}}$, Greivin Perez-

5 Rojas $^{\mathrm{a}, \mathrm{c}}$, Marta Perez-Villanueva ${ }^{\mathrm{a}, \mathrm{c}}$, Alejandro Perez Carrera ${ }^{\mathrm{b}}$, Alicia Fernández-Cirellib ${ }^{\mathrm{b}}$, Zisis

$6 \quad \operatorname{Vryzas}^{\mathrm{a}^{*}}$

7

$8{ }^{\mathrm{a}}$ Laboratory of Agricultural Pharmacology and Ecotoxicology, Department of Agricultural

9 Development, Democritus University of Thrace, 68200 Orestias, Greece

$10 \quad{ }^{\mathrm{b}}$ Centro de estudios transdisciplinarios del agua/ CETA(UBA); Instituto de Investigaciones en

11 Producción Animal/INPA (CONICET), Facultad de Ciencias Veterinarias, Universidad de

12 Buenos Aires. C1427CWO, Buenos Aires, Argentina

$13{ }^{\mathrm{c} C e n t r o}$ de Investigación en Contaminación Ambiental (CICA), Universidad de Costa Rica,

142060 San Jose, Costa Rica

15

16 * Corresponding Author: Zisis Vryzas, zvryzas@agro.duth.gr 
ABSTRACT

The presence of pesticide residues in groundwater, many years after their phase out in European Union verifies that the persistence in aquifer is much higher than in other environmental compartments. Factors such as limited degradation, and adsorption in phreatic horizon have resulted in frequent detection of pesticide residues and their metabolites in the saturated zone. Currently used and banned pesticides were monitored in Northern Greece aquifers and risk to human health was assessed. The target compounds were the herbicides metolachlor, terbuthylazine, atrazine and its metabolites Deisopropylatrazine (DIA), Deethylatrazine (DEA) and Hydroxyatrazine (HA). The area's aquifer has been extensively studied over the past 20 years. Eleven sampling sites were selected in order to have representatives of different type of wells. Namely, five drinking water, two irrigation wells and four experimental boreholes located close to Greek/Turkish/Bulgarian borders were monitored and fifty-four samples were analyzed. Pesticides were extracted by solid-phase extraction and analyzed by liquid chromatography. Metolachlor was detected in $100 \%$ of water samples followed by ATR (96.4\%), DEA and HA (88.6\%), DIA (78.2\%) and TER (67.5\%). Atrazine, DIA, DEA, HA, MET and TER mean concentrations detected were $0.18,0.29,0.14,0.09,0.16$ and $0.15 \mu \mathrm{g} / \mathrm{L}$, respectively. Obtained results were compared with historical data from our previous monitoring studies (1999-2003 and 2010-2012) and temporal trends were assessed. Preferential flow was the major factor facilitating pesticide leaching within the month of herbicide application. Moreover, apparent age of groundwater and the reduced pesticide dissipation rates on aquifers resulted of long-term detection of legacy pesticides. Although atrazine had been banned more than 15 years ago, it was detected frequently during our monitoring campaign and their concentrations in some cases were over the maximum permissible limit. Furthermore, human health risk assessment of pesticides was calculated for two different age groups though drinking water consumption. The presence of atrazine residues causes concerns related with chronic toxicity. 
46 Keywords: herbicides; metabolites; banned pesticides; groundwater; preferential flow; 47 leaching.

\section{Introduction}

Safe drinking water from surface- and ground-water is essential for human health, quality of life and socio-economic development of humanity and is a prerequisite factor for the human population (Affum et al., 2018). Groundwater is the largest body of freshwater in the European Union. In Greece, $13.9 \%$ of total renewable resources is originated from groundwater. In Greece, the annual water consumption/requirements are mainly covered by groundwater use representing $36 \%$ in farming, $5 \%$ in public use and $1 \%$ in industrial production. Hence, the usual geophysical peculiarities of Greece render the groundwater pumping as the only source of drinking water (EUWI/MED, 2007; Vryzas et al. 2012c).

Herbicides are generally considered the most economical and effective way to control weeds in agricultural and non-crop environments. However, the increasing use of herbicides has caused water contamination and other environmental threats (Kalkhoff et al. 1998). Several studies have highlighted the potential risks that these compounds pose to public health; biodiversity; and non-target organisms, such as fish, algae and aquatic invertebrates (Papadakis et al. 2015; Singh et al. 2017). There are several factors that can affect pesticide and their metabolites behavior in the environment. Physicochemical properties of pesticides such as ionization, water solubility, volatility, octanol-water partition coefficient, thermo-, photo- and hydrolysis stability combined with the soil properties including organic carbon content, texture, $\mathrm{pH}$, clay mineral type, dissolved organic matter and cation exchange capacity play important role on run-off, adsorption, or leaching potential. In addition, rainfall and irrigation intensity, biological processes (biodegradation) and the agricultural practices have influence on pesticide fate (Vryzas et al. 2007; Carazo-Rojas et al. 2018). Point or nonpoint source pesticide pollution can cause groundwater contamination through various leaching mechanisms. Pesticides residues can reach groundwater in a short time following various paths, they are able to move 
through soil matrix, rapidly by macropores with reduced possibility to be absorbed by soil or to be biodegraded. Macropores are caused by worm activity, roots, cracks, shrinkage of clay minerals and voids in soil (Vryzas et al. 2012b; Vryzas et al. 2012c). Otherwise, pesticides move through soil micropores slowly (matrix flow) and are available to interact with soil particles and microorganisms (Hasegawa and Sakayori, 2000).

Herbicides such as terbuthylazine (TER) (N-tert-butyl-6-chloro-N) -ethyl-1,3,5-triazine-2,4diamine), metolachlor (MET) [2-chloro-N- (2-ethyl-6methylphenyl) - N- (2-methoxy-1methylethyl) acetamide) and atrazine (ATR) (2-chloro-4-ethylamino-6isopropiamino-striazine), have been widely used for weed control in many crops in Greece, EU and around the world. However, Commission decision 2004/248/EC banned the use of active substance atrazine in EU (Charizoupoulos and Papadopoulou-Mourkidou 1999; Kolpin et al. 1998; Cerejeira et al. 2003; Kostantinou et al. 2006; Vryzas et al. 2009;) and terbuthylazine became the main herbicide used instead of atrazine after its withdrawal.

During the last three decades, various directives regulated the presence of pesticides in groundwater such as Ground Water Directive (EC 2006), Drinking Water Directive (EC, 1998), Water Framework Directive (EC, 2000) and Directives about priority substances and environmental quality standards in the field of water policy (EC 2008). The quality standards of drinking water, related to pesticides in EU, were set with maximum concentration of $0.1 \mu \mathrm{g}$ / $\mathrm{L}$ and $0.5 \mu \mathrm{g} / \mathrm{L}$ of the presence of individual and total pesticides and metabolites, respectively (EC 1998). In addition, EU has set environmental quality standards (EQS) for surface water bodies in the field of water policy for priority substances and certain other pollutants, including pesticides. According to this directive the annual average EQS for atrazine has set to $0.6 \mu \mathrm{g} / \mathrm{L}$ and the maximum allowable EQS to $2 \mu \mathrm{g} / \mathrm{L}$ (EC 2008). U S Enviromental Protection Agency (USEPA) has set Maximum Contaminant Levels (MCLs) and Maximum Contaminant Level Goals (MCLGs) of atrazine to $3 \mu \mathrm{g} / \mathrm{L}$ (USEPA, 2019).

The greatest part of the available information about atrazine toxicity impacts are coming from animal studies. Although, there are a few toxic (at cellular level) and epidemiological (case) studies considering the direct atrazine exposure implications on human health. Recent research 
showed that atrazine exposure to population may threaten public health. Mainly, atrazine is considered as an endocrine disruptor causing disfunction in extreme exposing conditions at normal human reproduction and development for both genders. Furthermore, atrazine exposure was correlated to potential neurological and liver problems (Singh et al. 2018; Yang et al. 2019). For atrazine transformation products there are only animal tests, which indicates similar effects with parent compound (Stoker et al. 2013).

Farmers are usually exposed to terbuthylazine through inhalation and dermal contact, whereas the main exposure pathway for people no related to agriculture is considered to be the oral route by contaminated drinking water consumption and less often by dermal route (USEPA, 1995). Published data about terbuthylazine impacts on human are limited. The terbuthylazine and its metabolite desethyl-terbuthylazine detection in hair samples of exposed farm workers was not related to significant health problems but only slight to moderate irritation to the eyes and skin were observed (Mercadante et al. 2017).

Metolachlor belongs in Toxicity Category III for acute dermal, oral, and inhalation effects and is in Toxicity Category IV for dermal and eye irritation (USEPA 2009). Thorpe and Shirmohammadi (2005) showed that children who were exposed to a mixture of herbicides that contained metolachlor had a 7.6-fold increased chance of developing bone or brain cancer, leukemia, and lymphoma compared to unexposed children, while herbicide applicators in Iowa and North Carolina had increased risk of lung and prostate cancer when exposed to metolachlor (Rusiecki et al. 2006).

Northern Evros is one of the most important regions of agricultural economy in Greece. In addition to the extensive agricultural activity, the vicinity with transboundary rivers and different agricultural practices followed in Bulgaria and Turkey increase the complexity of studying the origin of pesticide pollution.

Previous monitoring studies of Northern Evros showed medium frequency detection of atrazine, metolachlor, terbuthylazine and atrazine metabolites, deisopropylatrazine (DIA) (amino-2-chloro-6-ethylamino-s-triazine), deethylatrazine (DEA) (2-amino-4-isopropylamino6-chloro-s-triazine) and hydroxyatrazine (HA) 4-(Ethylamino)-2-hydroxy-6-(isopropylamino)- 
1,3,5- triazine (Papastergiou and Papadopoulou-Mourkidou 2001; Vryzas et al. 2012c). Also, these compounds have been frequently detected in high concentrations including water quality standards exceedances in various European countries such as Spain (Menchen et al. 2017), Slovenia (Korosa et al. 2016), Hungary (Szekacs et al. 2015) and Portugal (Sanchez-Gonzalez et al. 2013). Consequently, these compounds are considered to be of the main pollutants detected in groundwater bodies all over the world. Therefore, the aim of this study was to investigate the water quality, the presence and the persistence of these compounds, to characterize their temporal and spatial variability in the aquifer and to characterize atrazine and its metabolites behavior 15 years after atrazine's ban. Last but not least, a chronic risk assessment of side effects on human health by consumption of contaminated drinking water was conducted. According to our knowledge, this study is the first one which is related with human health risk assessment in combination with the determination of pesticides residues in groundwater in Greece.

\section{Materials \& Methods}

\section{Studying area}

The choice of sampling area was based on results of previous studies which indicate the presence of target pesticides in groundwater, the intensive agricultural activity in Northern Evros and neighboring countries Bulgaria and Turkey (Fig 1). Samples were taken from 3 Groups of 11 sampling points, at Ardas Valley. A sampling network of shallow groundwater was established by our research team 20 years ago (Vryzas et al. 2012c) consisted of 4 experimental boreholes (Group A). Furthermore, 5 drinking water wells were included, which supply Orestiada town and local villages with potable water (Group B). In addition, two active irrigation wells were chosen (Group C) to include all available well types. The Groups form was: (Group A): A1, A2, A3, A4, (Group B): B1, B2, B3, B4, B5 and (Group C): C1, C2 (Table 1). Sampling points are located close to villages Rizia, Keramos, Plati, Fylakio, Elia, Arzos and Kastanies (Fig. 1). The study included 5 sampling campaigns and 50 samples were collected and analyzed. 
157 Each sample was collected in triplicate (3 sub-samples of $1 \mathrm{~L}$ volume each one), transported in

158 ice-boxes and stored under refrigeration until analyzed. Experimental borehole samples were 159 manually pumped using an experimental tube. The drinking water and irrigation wells were equipped with a pump system and samples were collected automatically before chlorination stage.

Reagents and chemicals

The pesticide standards had the highest available purity (>97\%) and were purchased by Dr. Ehrestrofer GmbH (Augsburg, Germany). The HPLC grades, acetonitrile, ethyl acetate, water and methanol for liquid chromatography were purchased by Riedel de Haen (Seelze, Germany). LiChrolut ${ }^{\circledR}$ EN Polymer-based solid-phase extraction cartridges with $200 \mathrm{mg}$ absorbent and 3 ml volume were purchased by Merck (Darmastdt, Germany). Individual pesticide standard solution in $1,10,50,100 \mu \mathrm{g} / \mathrm{ml}$, in methanol, for HPLC analysis. Mixed pesticide standard solutions in different concentrations were prepared, too. All standard solutions were stored at $20{ }^{\circ} \mathrm{C}$. Physicochemical properties of studied compounds are shown in Table 2.

\section{Sample preparation}

174 Groundwater samples were prepared for HPLC analysis using Solid Phase Extraction (SPE) for the multi-residue analysis. Water samples of $1 \mathrm{~L}$ were extracted by cartridges which were preconditioned with adding of $4 \mathrm{ml}$ methanol followed by $4 \mathrm{ml}$ deionized water. Samples were passed through cartridges at a flow rate of $5 \mathrm{ml} / \mathrm{min}$. Target compounds were eluted with $7 \mathrm{ml}$ methanol followed by $3 \mathrm{ml}$ ethyl acetate. Next, samples were concentrated under nitrogen stream at $50{ }^{\circ} \mathrm{C}$. Finally, samples were dissolved with $1.25 \mathrm{ml}$ of the initial HPLC mobile phase and stored at $-20{ }^{\circ} \mathrm{C}$ until instrumental analysis (Papadakis et al. 2006).

Instrumental analysis

183 Samples were analyzed by a HPLC/DAD equipped with autosampler (Finnigan Surveyor, 184 Thermo Scientific). The analytical column C18 Speedcore 100 x $4.6 \mathrm{~mm}$ was purchased by 
185 Fortis Technologies Ltd. (Cheshire, UK). Chromatographic data were processed by the 186 ChromQuest 5.0 software (Finnigan Surveyor, Thermo Scientific). The mobile phase was 187 consisted of acetonitrile (A) and water (W). The flow was set at $1.0 \mathrm{ml} / \mathrm{min}$ and the gradient included the following steps: the elution began at 20-80/A-W, 20-80/A-W (0-20 min.), 95-5/W-

189 A (20-25 min.), 95-5/A-W (25-26 min.) and 20-80/A-W (26-33 min). Total run time was 40 min. The injection volume was $25 \mu$. The column oven temperature was adjusted at $30{ }^{\circ} \mathrm{C}$. Metolachlor, terbuthylazine, DEA and DIA were detected at $220 \mathrm{~nm}$, while atrazine and HA at $240 \mathrm{~nm}$. For further confirmation of the target peaks, the UV absorption spectra taken at the apex of each sample were compared with those obtained from the standard solutions and control spiked samples. The quantification was done using external working standard calibration curves $(1,10,50,100 \mu \mathrm{g} / \mathrm{ml})$. The accuracy (recovery) and precision (repeatability) of the analytical method were evaluated with the analysis of fortified (at $0.1 \mu \mathrm{g} / \mathrm{g}$ and $0.5 \mu \mathrm{g} / \mathrm{g}$ ) tab water samples in sextuplicate. The limits of detection (LOD, $\mu \mathrm{g} / \mathrm{L}$ ) were determined as the lowest concentrations giving a response of three times the baseline noise of the analysis of three control samples. The limits of quantification ( $\mathrm{LOQ}, \mu \mathrm{g} / \mathrm{L}$ ) were determined as the lowest concentrations of a given compound in fortified samples that could be quantified with relative standard deviation lower than 20\%. Positive detections of atrazine, DIA, DEA, MET and TER were also confirmed with Gas chromatographic analysis using a Trace 2000 gas chromatograph connected with the GCQ plus ion-trap mass spectrometer (Thermoquest, Austin, Texas, USA). Gas chromatographic analysis was carried out on a $30 \mathrm{~m} \times 0.25 \mathrm{~mm}$ I.D., $0.25 \mu \mathrm{m}$ film thickness CP-SIL 8 CB (5\% phenyl, 95\% dimethylpolysiloxane) low bleed/MS column (Varian Analytical Instruments, The Netherlands) and the GC and MS operational conditions were those mentioned by Vryzas et al. (2009).

\section{Human Health Risk Assessment}

Human health risk assessment was conducted for atrazine, metolachlor and terbuthylazine. According to Li and Qian (2011) human health risk assessment of pesticides can provide information about the probability and the kind of effects to human population. In our case, oral 
exposure through drinking water consumption was considered as pathway to people. Risk assessment was divided to carcinogenic and non-carcinogenic one and two age groups, adults and children. Drinking water is provided to local population by wells located close to villages Elia, Arzos, Fylakio, Rizia and Kastanies (Fig. 1)

Chronic daily intake (CDI)

219 CDI shows the estimated intake amount of pesticide per kilogram body weight Eq. 1.

$C D I i=\frac{D_{I P} \times E F_{i} \times E D_{i}}{B W_{i} \times A T}$

221 The determination of the average daily intake ( $\left.\mathrm{D}_{\mathrm{IP}}\right)$ was estimated using the Eq. 2. This

222 equation is suggested by Muhammad et al. (2011), Papadakis et al. (2015) and Ali et al. (2017)

$223 \quad \mathrm{D}_{\mathrm{IP}}=\mathrm{C}_{\mathrm{i}} \times \mathrm{IR}_{\mathrm{i}}$

where $C_{i}(\mu \mathrm{g} / \mathrm{L})$ represents extreme and mean concentration of pesticide residues and $\mathrm{IR}_{\mathrm{i}}$ shows the intake rate of water $\left(0.87 \mathrm{~L} /\right.$ day for children and $1.41 \mathrm{~L} /$ day for adults liters per day). $\mathrm{EF}_{\mathrm{i}}$ is the exposure frequency (365 days per year for both age groups), $\mathrm{ED}_{\mathrm{i}}$ is the exposure duration (6 and 70 years for adults and children, respectively), $\mathrm{BW}_{\mathrm{i}}$ is equal to $70 \mathrm{Kg}$ for adults and 20 $\mathrm{Kg}$ for children and AT is the average lifespan (2190 and 25550 days for children and adults,

\section{Hazard Quotient (Non-carcinogenic risk assessment)}

232 To calculate the Hazard Quotient (HQ), CDI was divided with the respective reference dose of each compound (Eq. 3)

$234 \mathrm{HQ}=\mathrm{CDI}_{\mathrm{i}} / \mathrm{RfD}$

235 where RfD is the acute toxicity reference dose (USEPA 1999).

The RfD values for atrazine, metolachlor, terbuthylazine were $0.035,0.015$ and $0.008(\mathrm{mg} / \mathrm{Kg}$ day), respectively (IRIS 1994; FOOTPRINT 2014). When HQ values are equal or greater than 1 , the exposed part of population is under health risk. 
Multiple pesticides residues risk (HQs) can be calculated by the sum of HQ for individual 240 pesticide using the Eq. 4.

$241 \mathrm{HQs}=\sum_{i=1}^{n} H Q i$

Carcinogenic risk assessment

Carcinogenic risk (R) was calculated by the Eq. 4 (Kim et al. 2013; Papadakis et al 2015).

$\mathrm{R}=\mathrm{CDI} \times \mathrm{SF} \times \mathrm{ADAF}$

where $\mathrm{SF}$ is the cancer slope factor ( $\mathrm{mg} / \mathrm{Kg}$-day), which reflects the possibility of the individual pesticide to cause cancer and $\mathrm{ADAF}$ is an age factor considering the early life pesticide exposure ( 3 for children and 1 for adults). Among the studied pesticides the only available SF is for atrazine with value 0.22 , provided by IRIS.

\section{Results \& Discussion}

\section{Concentrations and detection frequency}

For all compound the LODs were ranged from 0.001 to $0.005 \mu \mathrm{g} / \mathrm{L}$ and LOQs from 0.01 to 0.05 $\mu \mathrm{g} / \mathrm{L}$. The recoveries were higher than $86 \%$ for all compounds with RSD lower than $15 \%$ at the two fortification levels tested. The sampling sites were in the Ardas valley, an aquifer vulnerable to pesticide contamination according to previous studies (Papastergiou et al. 2001; Vryzas et al. 2012c). All the target pesticides were detected in all group of groundwater samples (Table 3). Metolachlor was detected in $100 \%$ of water samples followed by ATR (96.4\%), DEA and HA (88.6\%), DIA (78.2\%) and TER (67.5\%). Atrazine, DIA, DEA, HA, MET and TER mean concentrations detected were $0.18,0.29,0.14,0.09,0.16$ and $0.15 \mu \mathrm{g} / \mathrm{L}$, respectively (Table 4). Atrazine mean concentration exceeded the maximum permissible limit of $0.1 \mu \mathrm{g} / \mathrm{L}$ in experimental boreholes A2 $(0.23 \mu \mathrm{g} / \mathrm{L})$ and A4 $(0.28 \mu \mathrm{g} / \mathrm{L})$, DIA concentration was found over the limit in A4 $(0.14 \mu \mathrm{g} / \mathrm{L})$, DEA in A1 $(0.13 \mu \mathrm{g}) / \mathrm{L})$ and A4 $(0.18 \mu \mathrm{g} / \mathrm{L})$ and HA in A2 $(0.30 \mu \mathrm{g} / \mathrm{L})$. As far as drinking water wells, atrazine was detected in concentration higher than $0.1 \mu \mathrm{g} / \mathrm{L}$ in B1 $(0.23 \mu \mathrm{g} / \mathrm{L}), \mathrm{B} 2(0.45 \mu \mathrm{g} / \mathrm{L})$ and B5 $(0.30 \mu \mathrm{g} / \mathrm{L})$, DIA in B1 $(0.14 \mu \mathrm{g} / \mathrm{L}), \mathrm{B} 3$ $(0.26 \mu \mathrm{g} / \mathrm{L})$ and B5 $(0.22 \mu \mathrm{g} / \mathrm{L})$ and HA mean concentration was lower than limit in all of 
drinking water wells. The results of irrigation wells indicated exceedances for atrazine in $\mathrm{C} 1$ $(0.20 \mu \mathrm{g} / \mathrm{L})$ and $\mathrm{C} 2(0.14 \mu \mathrm{g} / \mathrm{L})$, DIA in C1 $(1.99 \mu \mathrm{g} / \mathrm{L})$, DEA in $\mathrm{C} 1(0.23 \mu \mathrm{g} / \mathrm{L})$ and $\mathrm{C} 2(0.20$ $\mu \mathrm{g} / \mathrm{L})$ and $\mathrm{HA}$ in $\mathrm{C} 1(0.13 \mu \mathrm{g} / \mathrm{L})$. In experimental boreholes $\mathrm{A} 2$, A4, in drinking water wells $\mathrm{B} 1, \mathrm{~B} 2$ and $\mathrm{B} 3$ and in irrigation well $\mathrm{C} 1$ were observed exceedances for terbuthylazine. Also, metolachlor was detected in concentrations higher than $0.1 \mu \mathrm{g} / \mathrm{L}$ in all wells apart from B2, B3, B4 (Table 4). The most frequent exceedances of the maximum permissible limit of $0.1 \mu \mathrm{g} / \mathrm{L}$ for drinking water of all compounds were observed in drinking water well B5 followed by C1, C2,

274 B1 and A4. The fact that target compounds reached concentrations above the quality standard 275 values for drinking water indicates that prediction made during pesticides registration process are not always complied with the results from monitoring studies. It is estimated that less than $1 \%$ of the pesticides applied reach the target pest and the remaining distributed to various environmental compartments including groundwater bodies (Pimentel and Levitan 1986). The most frequent exceedances of the maximum permissible limit of $0.1 \mu \mathrm{g} / \mathrm{L}$ for drinking water were observed in irrigation well of Fylakio $\mathrm{C} 1$ (for all 6 compounds), followed by the experimental borehole Fylakio A4 (for all compounds apart the HA). In a previous study was 282 found that waters of that site consisted of a mixture of waters with different residence time and 283 various leaching mechanisms are involved to the pollution of groundwater (Vryzas et al. 2012a). The only well with concentrations of the studied compound lower than $0.1 \mu \mathrm{g} / \mathrm{L}$, was the drinking water in Arzos B4. The active substance terbuthylazine is approved and applied by farmers in agricultural area of Ardas valley as a pre-emergence herbicide for maize, corn and beet cultivation in April, instead of metolachlor. Irrigation (repeated each week, during summer) is usually carried out by a self-propelled sprinkler irrigation system. These sprinkler irrigation systems provide high volumes of highpressure water, which in combination with rainfall can exacerbate the phenomenon of leaching (Vryzas et al. 2012b). Furthermore, there are a few paddies which are irrigated by basin 
irrigation systems. Nouma et al. 2016 mentioned that basin irrigation systems are the most

296 factor that determine pesticides leaching.

297 The highest concentration of atrazine $(1.81 \mu \mathrm{g} / \mathrm{L})$ was found in drinking water well of Fylakio 298 (B2) on third sampling, while atrazine did not detect in drinking water of Fylakio (B2) and Rizia (B1) on first sampling. DIA presented the highest concentration $(2.58 \mu \mathrm{g} / \mathrm{L})$ in irrigation well of Fylakio (C1) and detected in all sampling points with the lowest concentration in experimental boreholes. DEA had the highest concentration $(0.65 \mu \mathrm{g} / \mathrm{L})$ in experimental borehole of Fylakio (A4) at second sampling and wasn't detected in experimental boreholes of Fylakio (A4), Plati (A3) and Keramos (A2) at second and third sampling campaigns. The highest concentration of HA $(0.30 \mu \mathrm{g} / \mathrm{L})$ detected in irrigation well of Fylakio $\mathrm{C} 1$ and wasn't detected in drinking water and irrigation well of Fylakio (A4 andC1) and in drinking water well and experimental borehole of Rizia (A1 and B1) at first and second sampling. The highest concentration of metolachlor $(0.93 \mu \mathrm{g} / \mathrm{L})$ was detected in experimental borehole of Fylakio (A4). Terbuthylazine presented the highest concentration $(1.00 \mu \mathrm{g} / \mathrm{L})$ in the experimental borehole of Keramos (A2). It is worth noting that atrazine's metabolites were often found in higher concentrations than their parent compound.

The annual average concentrations for atrazine, DIA, DEA, HA, metolachlor and terbuthylazine were $0.17 \mu \mathrm{g} / \mathrm{L}, 0.28 \mu \mathrm{g} / \mathrm{L}, 0.13 \mu \mathrm{g} / \mathrm{L}, 0.06 \mu \mathrm{g} / \mathrm{L}, 0.09 \mu \mathrm{g} / \mathrm{L}$ and $0.14 \mu \mathrm{g} / \mathrm{L}$, respectively. The annual average concentration of atrazine and its maximum concentration detected were below the annual average EQS for atrazine $(0.6 \mu \mathrm{g} / \mathrm{L})$ and the maximum allowable EQS ( $2 \mu \mathrm{g} / \mathrm{L})$, respectively (EC 2008).

The distribution of pesticide concentrations in all wells was examined by applying the Box and Whisker Plot (Fig. S1). Figure S1 shows the distribution of median, quartile, non-outlier, outlier and extreme concentrations of compounds found in the studied wells.

The maximum concentrations detected in this study are within the range of concentrations detected in groundwater samples at the European level. Menchen et al. (2017), has recorded the maximum concentrations for atrazine $(0.38 \mu \mathrm{g} / \mathrm{L})$, metolachlor $(0.23 \mu \mathrm{g} / \mathrm{L})$, DEA $(0.12 \mu \mathrm{g} / \mathrm{L})$, DIA $(0.21 \mu \mathrm{g} / \mathrm{L})$ and terbuthylazine $(0.90 \mu \mathrm{g} / \mathrm{L})$. According to Meffe et al. (2014), the 
maximum concentrations for terbuthylazine in Italian groundwater was $29.05 \mu \mathrm{g} / \mathrm{L}$. Considerable higher maximum concentrations were found by Jurado et al. (2012), atrazine (3.45 $\mu \mathrm{g} / \mathrm{L})$, metolachlor $(5.37 \mu \mathrm{g} / \mathrm{L})$, DEA $(1.98 \mu \mathrm{g} / \mathrm{L})$ and terbuthylazine $(1.27 \mu \mathrm{g} / \mathrm{L})$. Hernandez et al. (2008) found that DIA was the most frequent detected compound (72\%), followed by terbuthylazine (50\%), with maximum concentrations of $1.42 \mu \mathrm{g} / \mathrm{L}$ for DEA 0.4 $\mu \mathrm{g} / \mathrm{L}$ for DIA and $0.46 \mu \mathrm{g} / \mathrm{L}$ for terbuthylazine. Also, a third Spanish study in agricultural areas showed maximum concentration $0.327 \mu \mathrm{g} / \mathrm{L}$ for atrazine $0.369 \mu \mathrm{g} / \mathrm{L}$ for DEA, $0.335 \mu \mathrm{g} / \mathrm{L}$ for terbuthylazine and $0.548 \mu \mathrm{g} / \mathrm{L}$ for metolachlor with detection frequency ranged from $4 \%$ (DEA) to $68 \%$ (metolachlor). The same study presented results from Portuguese groundwater in agricultural areas. Terbuthylazine had the highest concentration $(1.885 \mu \mathrm{g} / \mathrm{L})$ with detection frequency reached $56 \%$, followed by atrazine $(0.191 \mu \mathrm{g} / \mathrm{L})$ and detection frequency $25 \%$. DEA and metolachlor concentration were lower than $0.1 \mu \mathrm{g} / \mathrm{L}$ (Samchez-Gonzalez et al. 2013). According to Korosa et al. (2016), in groundwater samples from Slovenia atrazine and DEA were detected at concentrations up to $0.228 \mu \mathrm{g} / \mathrm{L}$ and $0.103 \mu \mathrm{g} / \mathrm{L}$ and their frequency of detection was $94.6 \%$ and $98.2 \%$ respectively. On another study which was conducted in United Kingdom and France, the highest concentrations from British groundwaters for atrazine, DIA, and DEA were $0.2,0.1$ and $0.16 \mu \mathrm{g} / \mathrm{L}$, respectively. On the other hand, the highest concentrations were found lower than $0.1 \mu \mathrm{g} / \mathrm{L}$, in France (Lapworth et al., 2015).

\section{Historical vulnerability of the transboundary aquifer to contamination by pesticide residues}

Target compounds had been monitored previously (between 1999-2003), at the same locations, before atrazine ban in EU. Also, a similar study was conducted between 2010-2012 (data not shown), confirming the occurrence of atrazine, DEA, DIA, and metolachlor (Vryzas et al. 2012c). In order to have a better perspective on pollution temporal trends, our data were compared with those of 1999-2003. Fifteen to nineteen years ago metolachlor had been detected at least once in $63 \%$ of the wells followed by atrazine (61\%), DEA (50\%), alachlor (47\%) and DIA (34\%). According to Vryzas et al. (2012c), maximum concentrations for atrazine (1.48 $\mu \mathrm{g} / \mathrm{L})$, DEA $(0.76 \mu \mathrm{g} / \mathrm{L})$, DIA $(0.071 \mu \mathrm{g} / \mathrm{L})$ and metolachlor $(1.54 \mu \mathrm{g} / \mathrm{L})$ had been detected at 
the same drinking water wells sampled in this study and considerable higher pesticide

352 concentrations were detected in shallow groundwater from experimental boreholes (Table 3).

353 Vulnerability of the aquifer to pollution depend on the land uses, soil properties, geological characteristics of the unsaturated zone, the hydraulic properties, the depth of the vadose zone and the leaching potential or physicochemical properties of the contaminant.

Due to the metolachlor and atrazine effectiveness against corn weeds and the limited available herbicides, both of them were extensively used during the period 1980-2005. The atrazine withdrawal in 2004, bring out the terbuthylazine as the most used herbicide, until nowadays. The cropping system and major crops has been gradually changed from 2005 till now. However, field crops are still the major crops in the area and the irrigation practices are the same used 2040 years ago (frequent sprinkler irrigation.

According to previous studies focused in this area, atrazine degraded faster than metolachlor in all soils of the vadoze zone and the biotransformation rates of both compounds decreased as metabolites of atrazine and metolachlor were found at higher concentrations in the $10-20 \mathrm{~cm}$ layers of all soil cores studied $(0-110 \mathrm{~cm}$ bgs). However, the enhanced biodegradation rates of atrazine in these soils is not enough to prevent the contamination of groundwater bodies. Similar results have been observed by other studies. According to McMahon et al. (1992);

371 Kolpin et al. (1997) and Steele et al. (2008), degradation rates of triazine parent compounds are 372 slower than their transport rates in groundwater.

373 Adsorption studies of atrazine, DEA, DIA, HA and metolachlor were also conducted in soils from five (0-10, 10-20, 20-40, 40-80, 90-110 cm bgs) different depths (Vryzas et al. 2007). This study revealed that when pseudo-equilibrium stage reached, the amount of compounds adsorbed accounted only for 10, 14, 27, 43 and $94 \%$ of the initial amount of DEA, DIA, atrazine, metolachlor and HA, respectively, spiked to the soils. According to this study, it was expected that more than 57 and $73 \%$ of the applied dose of metolachlor and atrazine, 
respectively, to be desorbed into the soil water and be available for leaching to deeper soil layers (Vryzas et al. 2007). In addition, to low adsorption capacity of atrazine and metolachlor within soil profile of the studied area, it was proved that the preferential flow is a major pesticide leaching mechanism in this area since pollutants can reach the saturated zone of the aquifer through preferential flow paths (shrinkage of the clay minerals, plant roots, earthworms forming burrows) without going through chromatographic flow within unsaturated zone and thereby circumventing the degradation processes (Vryzas et al.2012b). Studies on the apparent age of the studied aquifers shown that the residence time of groundwater bodies ranged from 1.2 to 50 years (Vryzas et al. 2012c). The leaching mechanisms prevailed in this area has been also studied in an extensive four-year field experiment focused on soil water samples taken from $0-25,35,60,100$ and $160 \mathrm{~cm}$ bgs (Vryzas et al. 2012b). According to this study, metolachlor, atrazine, DEA and DIA were detected in more than $67 \%$ of the total soil water samples. The main conclusion of this study was that the corn-applied herbicides have been leached below the surface soil via macropore-dominated pathways in less than one month after their application. Agricultural practices (application of pesticides and sprinkler irrigation) used in this area, soil structure and hydrogeological conditions increase the leaching potential of pesticides in the studied area. It is worth notice that alachlor another banned herbicides, with very limited half-life period $\left(\mathrm{DT}_{50 \mathrm{field}}=14\right.$ days $)$ had been detected in soil water of the studied area at concentrations greater than $0.1 \mathrm{mg} / \mathrm{L}$ up to 40 months after its application.

Also, as recommend by Vryzas, et al. (2012b), the late pesticide application, use of drip instead of sprinkler irrigation and delayed first irrigation seem to be the major management actions according to good agricultural practice that prevent pesticide leaching to groundwater in a semiarid Mediterranean region. The limited spatial and temporal variation of concentration levels observed in studied wells indicates a continuous load of the aquifer with the target compounds. The continuous use of high amounts of atrazine for more than 30 years was enough to contaminate the soil and aquifer and to be detected with its metabolites in groundwater 15 years after its last use (2004). However, illegal applications cannot be excluded since the studied area is $20 \mathrm{~km}$ from Greek/Turkish/Bulgarian borders and illegal trade of banned 
pesticides had been observed. Metolachlor has been used in the area for more than 40 years and terbuthylazine is mainly used the last 15 years.

Contrary to the results obtained 15 to 19 years ago extreme concentrations were not observed in this study, indicate the absence of point source pollution sites nearby the studied wells. Moreover, the studied compounds (metolachlor and terbuthylazine) were used in reduced quantities due to the changes of crop profile of the area or not used at all (ban of atrazine) compared the situation prevailed when previous studies were conducted (Vryzas et al 2012a).

\section{DEA to atrazine ratio $(D A R)$}

DEA to atrazine ratio (DAR) has been used to categorize point- and non-point source pollution of groundwater and in order to characterize the degradation and transport of atrazine in response to its metabolite DEA. This ratio can give us an indication of the major leaching mechanisms contribute to the pollution of groundwater and the capacity of the unsaturated zone to biodegrade atrazine to DEA. During the transport of atrazine through chromatographic flow within the biological more active unsaturated zone it could be metabolized in significant amounts by microorganisms to DEA (Adams and Thurman 1991; Goolsby et al. 1997; Vryzas et al. 2012b). In such cases the DAR would have values higher than 0.4 or even close 1 . Contrary, when atrazine bypasses the vadose and enters the saturated zone through preferential flow the contact time between atrazine and soil microbial community could be shorter and, therefore, the DAR ratio would be less than 0.4. The DAR ratio can provide information about atrazine leaching behavior based on the fact that atrazine represents a closer adsorption capacity to DEA than to HA in spite of HA was found as the main metabolite of atrazine at same area. In addition, this soil can adsorb higher amount of atrazine than DEA. Therefore, DEA can be leached faster than atrazine through chromatographic or preferential flow (Vryzas et al. 2007). The calculated DAR in this study was found to be higher than 1 in some cases and lower the 1 in most samples (Table 5) indicating that contamination in some cases comes from diffuse sources but most probably the bound atrazine was gradually desorbed from the soil matrix to the soil water and moved to groundwater through preferential flow (Hildebrandt et al. 2008; 
Vryzas, et al 2012b; Koch-Shulmeyer et al. 2014; Vonberg et al. 2014). Our results are in agreement with those of Vryzas et al. (2012a) conducted in the same area 15-19 years ago who found similar DAR values few months after the application of atrazine. Overall, atrazine's degradation products showed similar and, in few cases, higher concentrations than did the parent compound. DIA exhibits a large range of concentrations varying between $0.01 \mu \mathrm{g} / \mathrm{L}$ and $2.91 \mu \mathrm{g} / \mathrm{L}$. According to biotransformation studies conducted in the soil profile of the studied area HA was the most frequently detected metabolite and with the highest concentrations. The second most frequently detected degradation product in soil was DEA, followed by rare DIA detections (Vryzas et al. 2012). The overwhelming majority of soil water samples with DEA presence, showed DEA had greater concentrations than DIA and the ratio values CDEA/CDIA reached 33 (Vryzas et al. 2012b). Similarly, DEA (50\% of groundwater samples) was more frequently detected than DIA (34\% of groundwater samples) in an extensive groundwater monitoring program conducted in the same area 15-19 years ago (Vryzas et al. 2012c). Contrary to previous reported data, in our study, atrazine and its metabolites were detected with similar frequency of detection.

\section{Risk assessment}

An extended discussion was preceded related to the presence, occurrence and distribution reasons of target pesticides at studied area. Results on human health risk assessment are presented in Table 6. Although, the HQ values for individual pesticide did not exceed the value 1, the estimated non-carcinogenic risk for children was higher, when compared to adults. The HQ values for mean pesticides concertation were ranged between 0.0171 to 0.1913 for adults and between 0.0393 to 0.5752 for children. The highest mean values are reported to metolachlor and the lowest to atrazine. The highest HQ values were determined in drinking water well close to Rizia namely, 0.2507 and 0,7817 for adults and children, respectively. Similar HQ values for atrazine and metolachlor in drinking water were reported by Papadakis et al. (2015). The risk level for terbuthylazine is low with HQ values lower than 0.6. 
The sum of HQ values did not reach the unity in all studied wells. The greatest cumulative potential risk was determined in the Rizia well with values 0.2836 and 0.8299 for adults and children, respectively. The lowest potential risk has the Elia well, with values lower than 0.4. Consequently, according to the acute risk assessment, the studied drinking water wells were characterized safe.

Oppositely, the carcinogenic risk assessment showed high values. In all cases, atrazine $\mathrm{R}$ values were higher than the parametric one of $1 \times 10^{-6}$ recommended by USEPA, for both age groups, showing that the local population is under carcinogenic risk (table 6). The water consumption through Fylakio well presents the highest risk, while Arzos well the lowest. The R values are ranged between $0.002-0.0018$ for adults and 0.0012- 0.0181 for children. Papadakis et al. (2015), in a similar study, indicate high carcinogenic risk only for children.

\section{Conclusions}

Although agricultural use of atrazine has been banned in Greece for more than 15 years ago, atrazine and its metabolites residues are still detected in groundwater of the region, indicating their high persistence in saturated zone.

Among the compounds included in this study metolachlor was detected in $100 \%$ of samples followed by atrazine (96.4\%), DEA and HA (88.6\%), DIA (78.2\%) and terbuthylazine $67.5 \%$.

Atrazine, DIA, DEA, HA, MET and TER mean concentrations detected were 0.18, $0.29,0.14,0.09,0.16$ and $0.15 \mu \mathrm{g} / \mathrm{L}$, respectively

DIA, terbuthylazine, atrazine, metolachlor, DEA and HA exceeded the critical pesticide limit for drinking water of $0.1 \mu \mathrm{g} / \mathrm{L}$ in $58 \%, 50.5 \%, 38 \%, 35.9 \%, 30 \%$ and $15.5 \%$ of the total number of samples for each compound, respectively.

$\square$ All pesticides were detected in both shallow and deep ground-water bodies (experimental boreholes, drinking or irrigation water wells). 
Although the repeated application of studied pesticides could lead to enhanced biodegradation, as previously reported in the studied area, the remaining amounts of bound residues was gradually desorbed from the soil matrix to the soil water and moved to groundwater through preferential or chromatographic flow.

492

Due to the presence of occasional point-sources pollution were detected extreme concentrations.

$\square$ The drinking water consumption for local people is safe considering the acute risk assessment.

497

498

499

\section{Acknowledgement}

500

501 This project has received funding from the European Union's Horizon 2020 research and 502 innovation programme under the Marie Skłodowska-Curie grant agreement No 690618. The 503 article reflects only the author's view and the Agency is not responsible for any use that may 504 be made of the information it contains.

505

Ethical Approval

507 Not applicable

508

509 Consent to Participate

$510 \quad$ Not applicable

511

512

\section{Consent to Publish}

513 Not applicable 
Parlakidis Paraskevas, Alexoudis Christos, Fernández-Cirelli Alicia and Vryzas Zisis

517 conceived and planned the experiments, Parlakidis Paraskevas and Alexoudis Christos made 518 the sampling, Parlakidis Paraskevas, Rodriguez M. Soledad, Perez-Rojas Greivin and Perez519 Villanueva Marta made the extractions and instrumental analysis. Parlakidis Paraskevas, Zisis 520 Vryzas, Rodriguez M. Soledad, Perez Carrera Alejandro and Fernández-Cirelli Alicia wrote the 521 manuscript. All authors discussed the results and contributed to the final manuscript.

522

\section{$523 \quad$ Funding}

524 This work was supported by European Union's Horizon 2020 research and innovation 525 programme under the Marie Skłodowska-Curie grant agreement No 690618.

\section{Competing Interests}

528 Authors have no other competing interests

529

530

531

532

533

534

535

536

537

538

539

540

541

\section{Availability of data and materials}

The datasets used and/or analysed during the current study are available from the corresponding author on reasonable request.

\section{References}

Adams CD, Thurman EM (1991) Formation and transport of deethylatrazine in the soil and vadose zone. Journal of Environmental Quality 20: 540-547.

Affum AO, Acquaah SO, Osae SD, and Kwaansa-Ansah E (2018) Distribution and risk assessment of banned and other current-use pesticides in surface and groundwaters consumed in an agricultural catchment dominated by cocoa crops in the Ankobra Basin, Ghana. Science of the total environment 633: 630-640. 
Ali N, Kalsoom, Khan S, Ihsanullah, Rahman I, Said M (2017) Human Health Risk Assessment Through Consumption of Organophosphate Pesticide Contaminated Water of Peshawar Basin, Pakistan. Exposure and Health 10: 259-272.

Charizopoulos E, Papadopoulou-Mourkidou E (1999) Occurrence of pesticides in rain of Axios river basin, Greece. Environmental Science \& Technology 33(14): 2363-2368.

Cerejeira MJ, Viana P, Batista S, Pereira T, Silva E, Valerio MJ, Silva A, Ferreira M, SilvaFernandes AM (2003) Pesticides in Portuguese surface and ground waters. Water Research 37(5): 1055-1063.

Carazo-Rojas E, Perez Rojas G, Perez-Villanueva M, Chinchilla-Soto C, Chin-Pampillo JS, Aguilar-Mora P, Alpizar-Marin M, Masis-Mora M, Rodriguez-Rodriguez CE, Vryzas Z (2018) Pesticide monitoring and ecotoxicological risk assessment in surface water bodies and sediments of a tropical agro-ecosystem 2018. Environmental Pollution 241: 800-809.

European Parliament and Council, "Council Directive 98/83/EC of 3 November 1998 on the quality of water intended for human consumption”. Official Journal of the European Union. 330: $32-54$.

European Parliament and Council, "Directive 2000/60/EC of the council of 23 October 2000 establishing a framework for community action in the field of water policy". Official Journal of the European Union. 327(1).

European Parliament and Council, “Commission Decision 2004/248/EC of 10 March 2004 concerning the non-inclusion of atrazine in Annex I to Council Directive 91/414/EEC and the withdrawal of authorizations for plant protection products containing this active substance". Official Journal of the European Union. 731.

European Parliament and Council, "Directive 2006/118/EC of 12 December 2006 on the protection of groundwater against pollution and deterioration". Official Journal of the European Union. 372: 19-31.

EUWI/MED, Joint Mediterranean Process, (2007). Mediterranean Groundwater Report. Technical report on groundwater management in the Mediterranean and the Water Framework Directive. 
European Parliament and Council, "European Union Directive 2008/105/EC of the European Parliament and of the Council on environmental quality standards in the field of water policy”. Official Journal of European Union. 348: 84-97.

European Parliament and Council, "Directive 2013/39/EU of 12 August 2013 amending Directives 2000/60/EC and 2008/105/EC as regards priority substances in the field of water policy". Official Journal of the European Union. 226(1).

FOOTPRINT (2014) The FOOTPRINT Pesticide Properties Data Base. Database collated by (FP6-SSP-022704). 〈http://sitem.herts.ac.uk/aeru/footprint/en/index.htm〉, (accessed on 10 October 2020).

Goolsby DA, Thurman EM, Pomes ML, Meyer MT, Battaglin WA (1997) Herbicides and their metabolites in rainfall: origin, transport, and deposition patterns across the Midwestern and northeastern United States, 1990-1991. Environmental Science \& Technology 31: 13251333.

Hasegawa S, Sakayori T (2000) Monitoring of Matrix Flow and Bypass Flow through the Subsoil in a Volcanic Ash Soil. Soil Science Plant Nutrition 46: 661-671.

Hildebrandt A, Guillamón M, Lacorte S, Tauler R, Barceló D (2008) Impact of pesticides used inagriculture and vineyards to surface and groundwater quality (North Spain). Water Research 42: 3315-3326.

Hernández F, Marín JM, Pozo OJ, Sancho JV, López FJ, Morell I (2008) Pesticides residues and transformation products in groundwater from a Spanish agricultural region on the Mediterranean Coast. International Journal of Environmental Analytical Chemistry 88: 409424.

Hu Y, Qi S, Zhang J, Tan L, Zhang J, Wang Y, Yuan D (2011) Assessment of organochlorine pesticides contamination in underground rivers in Chongqing, Southwest China. J. Geochem 111: 47-55.

Hartnett S, Musah S, Dhanwada KR (2013) Cellular effects of metolachlor exposure on human liver (HepG2) cells. Chemosphere 90: 1258-1266. 
IRIS (1994) (Integrated Risk Information System) Oral chronic reference dose integrate risk information system database; toxicity and chemical specific factor database. (http://risk.Isd.ornl.gov/cig), (accessed on 10 October 2020).

Jurado A, Vázquez-Suñé E, Carrera J, López de Alda M, Pujades E, Barceló D (2012) Emerging organic contaminantsin groundwater in Spain: a review of sources, recent occurrence and fate in a European context. Science of the Total Environment 440: 82-94.

Kolpin DW, Kalkhoff SJ, Goolsby DA, Sneck-Fahner DA, Thurman EM (1997) Occurrence of selected herbicides and herbicide degradation products in Iowa's groundwater, 1995. Ground Water 35: 679-688.

Kolpin DW, Barbash JE, Gillom RJ (1998) Occurrence of pesticides in shallow groundwater of the United States: initial results from the National water-Quality assessment program. Environmental Science \& Technology 32: 558-566.

Kalkhoff SJ, Kolpin DW, Thurman EM, Ferrer I, Barcelo D, (1998) Degradation of chloroacetanilide herbicides: The prevalence of sulfonic and oxanilic acid metabolites in Iowa groundwaters and surface waters. Environmental Science \& Technology 32(11): 17381740.

Konstantinou IK, Hela DG, Albanis TA (2006) The status of pesticide pollution in surface waters (rivers and lakes) of Greece. Part I. Review on occurrence and levels. Environmental Pollution 141: 555-570.

Kim HH, Lim YW, Yang JY, Shin DC, Ham HS, Choi BS, Lee JY, (2013) Health risk assessment of exposure to chlorpyrifos and dichlorvos in children at childcare facilities. Sci. Total Environ 444: 441-450

Köck-Schulmeyer M, Ginebreda A, Postigo C, Garrido T, López de Alda M, Barceló D (2014) Four-year advanced monitoring program of polar pesticides in groundwater of Catalonia (NESpain). Science of the Total Environment 470-471: 1087-1098.

Lapworth DJ, Baran D, Stuart ME, Manamsa K, Talbot J (2015) Persistent and emerging microorganic contaminats in Chalk groundwater of England and France. Environmental pollution 203: 214-225. 
Korosa A, Auersperger P, Mali N (2016) Determination of micro-organic contaminants in groundwater (Maribor, Slovenia). Science of the Total Environment 571: 1419-1431.

Lovakovic BK, Pizent A, Kopjar N, Micek V, Mendas G, Dvorscak M, Mikolic A, Milic M, Zunec S, Lucic A, Zeljezic D (2017) Effects of sub-chronic exposure to terbuthylazine on DNA damage, oxidative stress and parent compound/metabolite levels in adult male rats. Food and Chemical Toxicology 108: 93-103.

McMahon PB, Chapelle FH, Jaguck IML, (1992) Atrazine mineralization potential of alluvialaquifer sediments under aerobic conditions. Environmental Science \& Technology 26: 15561559.

Muhammad S, Shah MT, Khan S (2011) Health risk assessment of heavy metals and their source apportionment in drinking water of Kohistan region, northern Pakistan. Microchemical Journal 98: 334-343.

Mercadante R, Polledri E, Giavin E, Menegola E, Bertazzi PA, Fustinoni S, (2012) Terbuthylazine in hair as a biomarker of exposure. Toxicology Letters 210: 169-173.

Mercadante R, Polledri E, Fustinoni S, (2012) Determination of terbuthylazine and desethylterbuthylazine in human urine and hair samples by electrospray ionization-liquid chromatography/triple quadrupole mass spectrometry. Analytical and Bioanalytical Chemistry 404: 875-886.

Meffe R, Bustamante I, (2014) Emerging organic contaminants in surface water and groundwater: a first overview of the situation in Italy. Science of the Total Environment 481: $280-295$.

Menchen A, De las Heras J, Gómez Alday J (2017) Pesticide contamination in groundwater bodies in the Júcar River European Union Pilot Basin (SE Spain). Environmental Monitoring and Assessment 189(146): 1-18.

Nouma BB, Rezig M, Bahrouni H (2016) Best Irrigation Practices Designed for Pesticides Use to Reduce Environmental Impact on Groundwater Resource in the Tunisian Context. Journal of Agricultural Science 8: 142-152. 
652

Pimentel D, Levitan L, (1986) Pesticides: amounts applied and amounts reaching pests. Bioscience 36(2): 86-91.

Papastergiou A, Papadopoulou-Mourkidou E (2001) Occurrence and spatial and temporal distribution of pesticide residues in groundwater of major corn-growing areas of Greece (1996-1997). Environmental Science \& Technology 35: 63-69.

Palma G, Sánchez A, Olave Y, Encina F, Palma R, Barra R (2004) Pesticide levels in surface waters in an agricultural-forestry basin in Southern Chile. Chemosphere 57: 763-770.

Papadakis EM, Papadopoulou-Mourkidou E (2006) LC-UV determination of atrazine and its principal conversion products in soli after combined microwave-assisted and solid-phase extraction. International Journal of Environmental Analytical Chemistry 86: 573-582.

Papadakis NE, Vryzas Z, Kotopoulou A, Kintzikoglou K, Makris CK, PapadopoulouMourkidou E (2015) A pesticide monitoring survey in rivers and lakes of northern Greece and its human and ecotoxicological risk assessment. Ecotoxicology and Environmental Safety 116: 1-9.

Rice PJ, Anderson TA, Coats JR (2002) Degradation and persistence of metolachlor in soil: effects of concentration, soil moisture, soil depth, and sterilization. Environmental Toxicology and Chemistry 21(12): 2640-2648.

Rusiecki JA, Hou L, Lee WJ, Blair A, Dosemeci M, Lubin JH, Matthew Bonner M, Samanic C, Hoppin JA, Sandler DP, Alavanja MCR, (2006) Cancer incidence among pesticide applicators exposed to metolachlor in the Agricultural Health Study. International Journal of Cancer 118: 3118-3123.

Steele GV, Johnson HM, Sandstrom MW, Capel PD, Barbash JE (2008) Occurrence and fate of pesticides in four contrasting agricultural settings in the United States. Journal of Environmental Quality 37 1116-1132.

Stoker ET, Hallinger DR, Seely JC, Zorrilla LM (2013) Evaluation of Hydroxyatrazine in the Endocrine Disruptor Screening and Testing Program's Male and Female Pubertal Protocols. Birth Defects Research (Part B) 98: 428-435. 
680 M J, Rodriguez-Cruz S (2013) Pesticide residues in groundwaters and soils of agricultural 681 areas in the Agueda River Basin from Spain and Portugal. International Journal of 682 Environmental Analytical Chemistry 93(15): 1585-1601.

683

Szekacs A, Mortl M, Darvas B (2015) Monitoring Pesticide Residues in Surface and Ground 684 Water in Hungary: Surveys in 1990-2015. Journal of Chemistry 685 http://dx.doi.org/10.1155/2015/717948.2015, pp 1-15.

686 Singh S, Kumar V, Chauhan A, Datta S, Basit Wani A, Singh N, Singh J (2018) Toxicity, 687 degradation and analysis of the herbicide atrazine. Envriomental Chemistry Letters 16: 211688237.

689 Thorpe N, Shirmohammadi A (2005) Herbicides and Nitrates in Groundwater of Marylandand 690 Childhood Cancers: A Geographic Information Systems Approach. Journal of Environmental 691 Science and Health Part C 23: 261-278.

692 USEPA (1995) Reregistration Eligibility Decision (RED) Terbuthylazine.

693 USEPA (1999) Definitions and general principles for exposure assessment: guidelines for 694 exposure assessment. Office of Pesticide Programs, Washington, DC

695 USEPA (2009) Health Effects Assessment for Asbestos. EPA, 1995. Re-registeration eligibility 696 (RED) facts: metolachlor. EPA-738-F-95-007.EPA prevention, herbicides, and toxic 697 substances.

698 USEPA (2019) "National Primary Drinking Water Regulations". 699 (https://www.epa.gov/ground-water-and-drinking-water/national-primary-drinking-water700 regulations), (accessed on 10 October 2020).

701 Vryzas Z, Papadopoulou-Mourkidou E, Soulios G, Prodromou K (2007) Kinetics and 702 adsorption of metolachlor and atrazine and the conversion products (deethylatrazine, 703 deisopropylatrazine, hydroxyatrazine) in the soil profile of a river basin. European Journal of $704 \quad$ Soil Science, 58: 1186-1199. 
Vryzas Z, Vassiliou G, Alexoudis C, Papadopoulou Mourkidou E (2009) Spatial and temporal distribution of pesticide residues in surface waters in north-eastern Greece. Water Research 43(1): $1-10$.

Vryzas Z, Papadakis E, Oriakli K, Moysiadis TP, Papadopoulou-Mourkidou E (2012a) Biotransformation of atrazine and metolachlor within soil profile and changes in microbial communities. Chemosphere 89: 1330-1338.

Vryzas Z, Papadakis EN, Papadpoulou-Mourkidou E (2012a) Leaching of Br-, metolachlor, alachlor, atrazine, deethylatrazine and deisopropylatrazine in clayey vadoze zone: A field scale experiment in north-east Greece. Water Research 46: 1979-1989.

Vryzas Z, Papadakis EN, Vassiliou G, Papadopoulou-Mourkidou E (2012c) Occurrence of pesticide in transboundary aquifers of North-eastern Greece. Science of the Total Environment 441: 41-48.

Vonberg D, Vanderborght J, Cremer N, Pütz T, Herbst M, Vereecken H (2014) 20 years of long-term atrazine monitoring in a shallow aquifer in western Germany. Water Research 50: 294-306.

Wang Q, Yang W, Liu W (1999) Adsorption of acetanilide herbicides on soils and its correlation with soil properties. Pesticide Science 55(11): 1103-1108.

Wu J, Xue C, Tian R, Wang S (2017) Lake water quality assessment: a case study of Shahu Lake in the semi-arid loess area of northwest China. Environ Earth Sci 76: 232.

Yang L, Li H, Zhang Y, Jiao N (2019) Environmental risk assessment of triazine herbicides in the Bohai Sea and the Yellow Sea and their toxicity to phytoplankton at environmental concentrations. Environment International 133: 105175. 

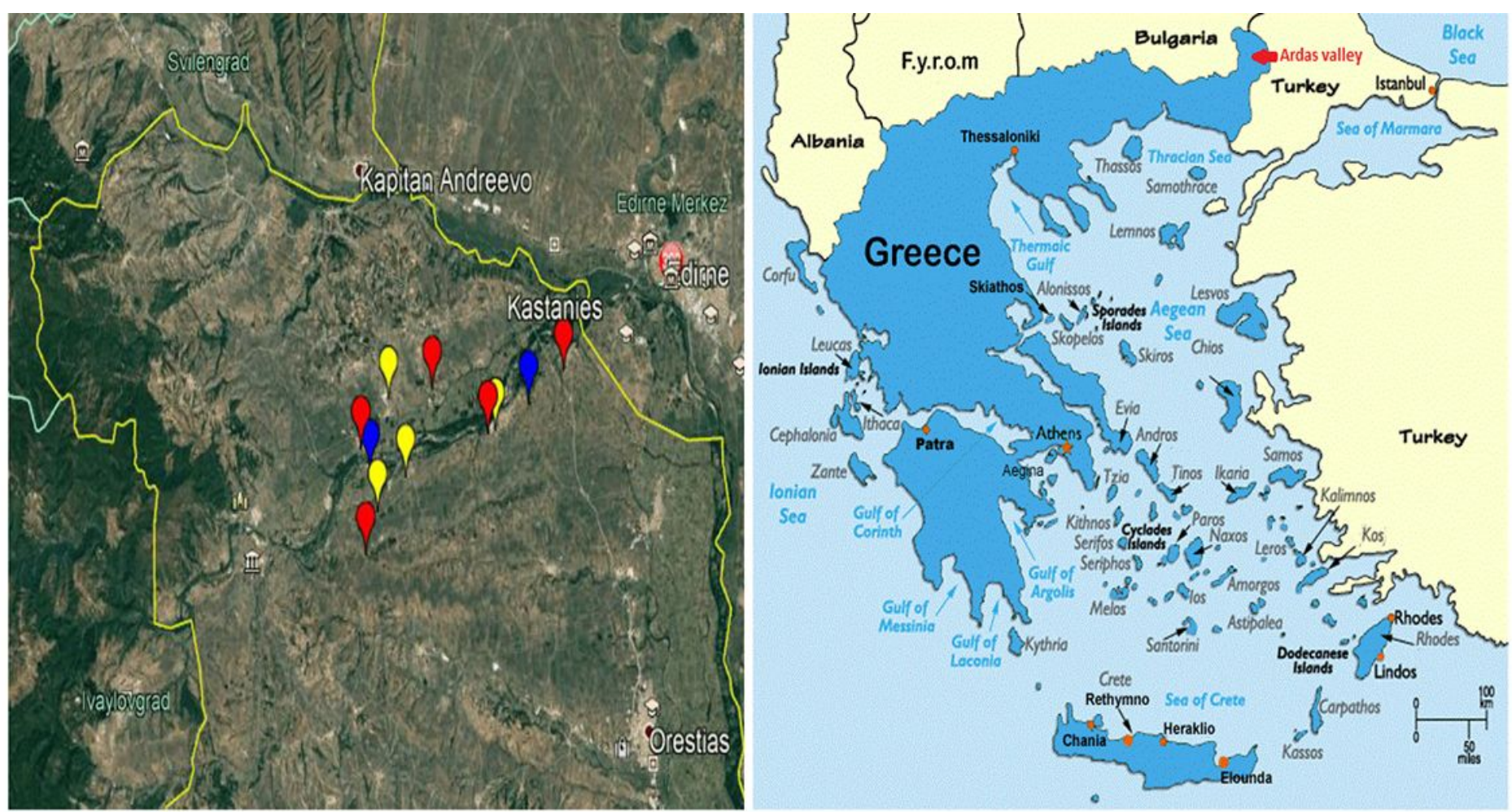

\section{Figure 1}

Sampling area of a transboundary aquifer, among Greece, Turkey and Bulgaria (picture on right). Yellow points: Experimental boreholes. Red point: drinking water wells. Blue points: irrigation wells (picture on left). Note: The designations employed and the presentation of the material on this map do not imply the expression of any opinion whatsoever on the part of Research Square concerning the legal status of any country, territory, city or area or of its authorities, or concerning the delimitation of its frontiers or boundaries. This map has been provided by the authors. 


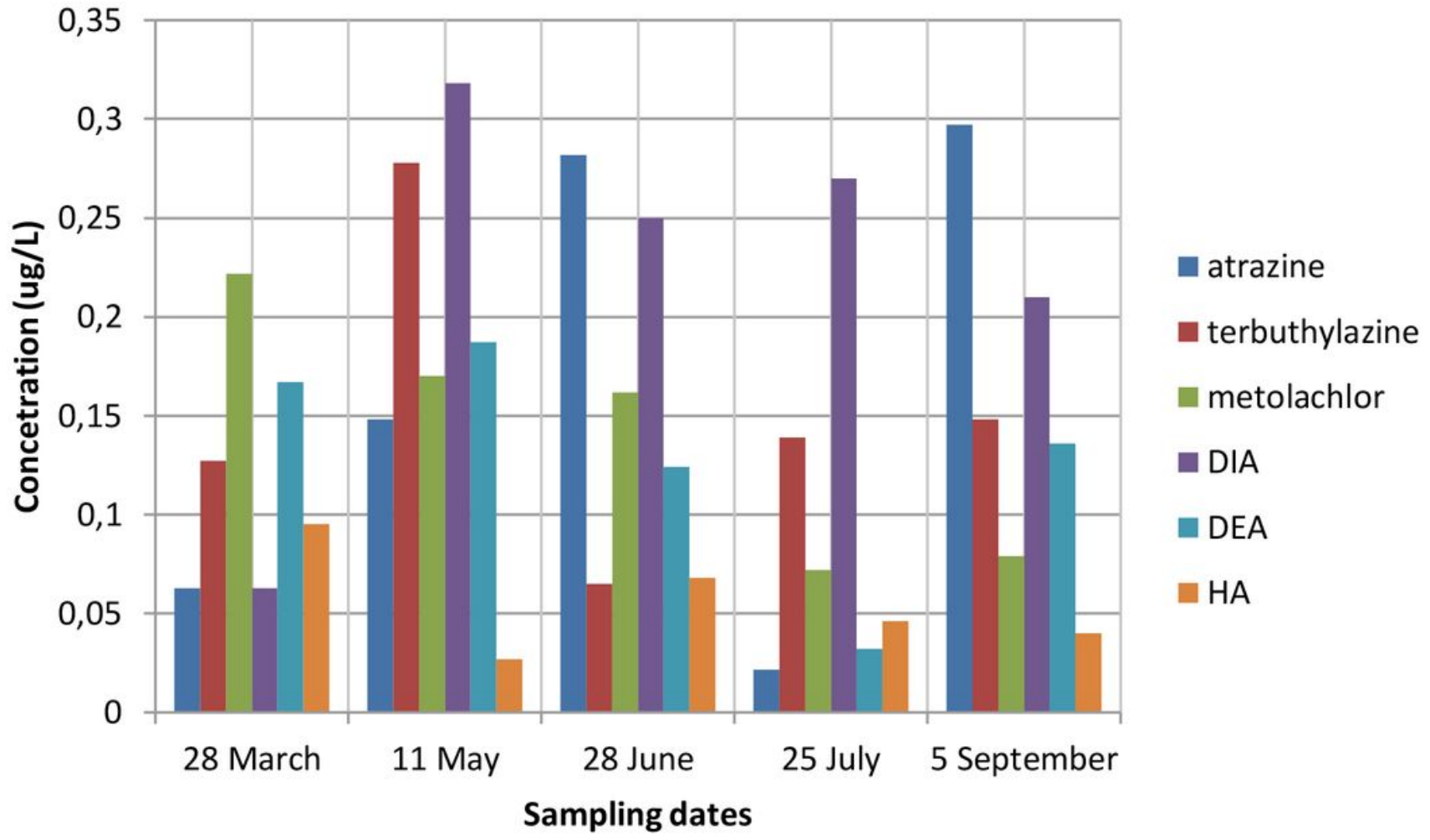

Figure 2

Mean compound concentrations in each sampling date. 


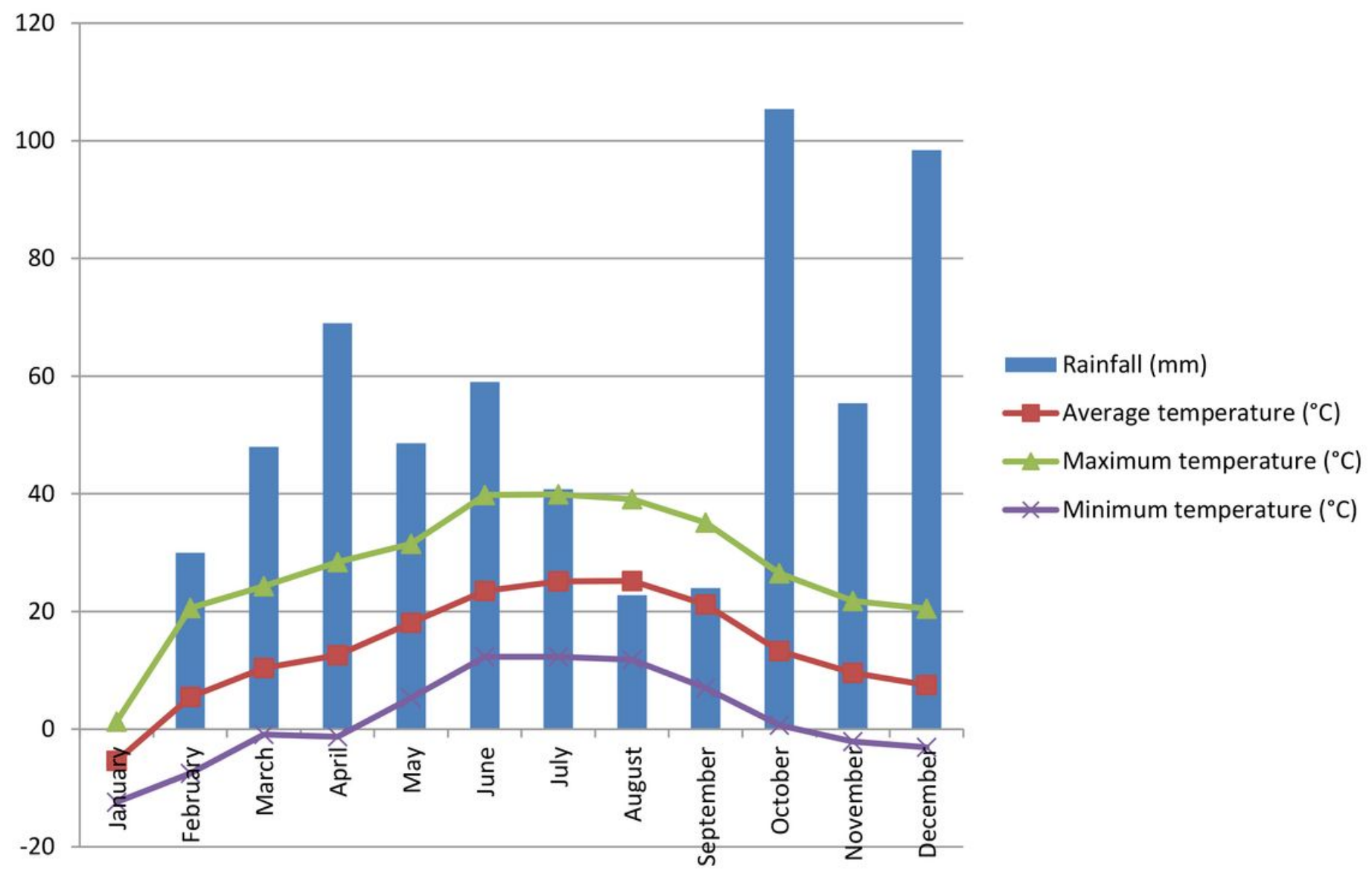

Figure 3

Meteorological data during the studying growing season.

\section{Supplementary Files}

This is a list of supplementary files associated with this preprint. Click to download.

- FigureS1..pdf

- GraphicalAbstract.pdf

- Table1..pdf

- Table2..pdf

- Table3..pdf

- Table4..pdf

- Table5..pdf 